\title{
Foreign Aid, Domestic Savings, And Economic Growth In South Asia
}

\author{
Hem C. Basnet, Chadron State College, USA
}

\begin{abstract}
The role of foreign aid in promoting growth by complimenting domestic savings has been an issue of considerable controversy. This study examines the role of foreign aid on domestic savings and economic growth in South Asian countries - Bangladesh, India, Nepal, Pakistan, and Sri-Lanka by using simultaneous equation system in which growth and savings are jointly determined. The results indicate that aid has a positive and significant effect on the growth rates of the five nations studied during 1960 to 2008. However, foreign aid appears to crowd out domestic savings rather than complementing it.
\end{abstract}

Keywords: Foreign Aid; Domestic Savings; Investment, Growth

\section{INTRODUCTION}

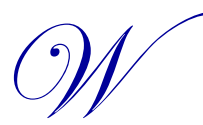

hile there are many reasons for giving foreign aid, the most notable argument is to bridge the gap between domestic saving and domestic investment and therefore, to accelerate growth. A fundamental assumption made by the supporters of aid is that it helps poor countries in achieving higher levels of economic growth. In the absence of such aid internal resources of the poor countries will not be able to take off (Dowling and Hiemenz, 1983). Additionally, since less developed countries are constrained by low foreign currency reserves aid can fill the foreign exchange gap as well as saving gap (Papanek, 1973). Hence, foreign aid is crucial in the process of economic development in developing countries. Even though, most of foreign aid has been targeted to promote economic growth and improve the well being of their citizens in developing countries, there has been significant debate over the effectiveness of aid in the recipient countries. Empirical studies related to foreign capital flow and economic growth show evidence for and against the theoretical arguments regarding the impact of foreign capital.

Griffin (1970), for instance, argues that foreign aid does not contribute to economic growth and that it fails to foster democratic political regimes. Instead, foreign economic assistance could retard economic development by lowering the domestic saving rate. Rajan and Subramanian (2008) also documents a similar conclusion to that of Griffin (1970). However, Papanek (1973), in a cross-country regression analysis of 34 countries in the 1950s and 51 countries in the 1960s, treating foreign aid, foreign investment, other flows and domestic savings as explanatory variables, finds that foreign aid has a substantially greater effect on growth than on the other variables. He explains that aid, unlike domestic savings, can fill the foreign exchange gap as well as the savings gap. He also finds a strong negative correlation between foreign aid and domestic savings.

Fayissa and El-Kaissy (1999), in a study of 77 countries over sub-periods 1971-1980, 1981-1990 and 19711990, show that foreign aid positively affects economic growth in developing countries. This is consistent with theory of foreign aid, which asserts that overseas development assistance accelerates economic growth by supplementing domestic capital formation (Chenery and Strout, 1966; Hatemi-J and Irandoust, 2005).

Studies that found negative associations between foreign aid and growth argue that government receiving aid generally do not raise taxes but expand consumption from money coming from external sources. That results in lower savings and thereby low growth. If capital inflow is high then domestic saving tends to decrease or even go negative if the foreign capital inflow is very high. In other words, domestic savings is not only the function of national income but also the function of foreign capital. In the literature some studies argue that the negative relation 
that might exist between foreign aid flows and economic growth is outcome of factors such as economic policies, state intervention, business cycles, and stability of foreign aid flows in the recipient countries. For instance, Burnside and Dollar (2000) argue that aid promotes economic growth but only in good policy environments. Boone (1996) finds the foreign aid does not increase economic growth rates in the typical poor countries. The logic in the paper follows Burnside and Dollar (2000) -- economic growth may depend on whether the recipients are pursuing sound economic policies.

Studies done in the Asian countries have found a positive association between aid and economic growth. Austria (2009) investigates the long-run relationship between foreign aid and economic growth in five South Asian economies and found a positive relationship between aid and GDP growth. Bhattarai (2009) examines the effect of aid on economic growth for Nepal and concludes that aid is positively related to per capita real GDP in the long-run. Burke and Almadi-Esfahani (2006) test the effectiveness of aid in promoting growth in three South East Asian countries using a simultaneous model in which growth and savings are jointly determined. Their findings indicate that aid had an insignificant effect on the growth rates of the sampling countries during 1970-2000 and did not displace domestic savings. Dhakal, Upadhyaya and Upadhyay (1996) conduct a causality test between foreign aid and economic growth for four Asian and four African countries and find that except for Kenya and Nepal, foreign aid is positively and significantly related to economic growth. Studies by Rana and Dowling (1988) and Dowling and Heimenz (1983) also found that foreign capital flows have made a positive contribution to the growth of Asian developing countries.

In this study we empirically investigate the role of foreign aid on domestic savings and economic growth in SAARC ${ }^{1}$ member countries. However, due to lack of data availability Bhutan and Maldives are not included in this study. Most of the past studies have focused on the relationship between aid inflows and economic growth. Very limited attention has been paid to test the impact of foreign aid on domestic saving in these countries. This study aims to investigate the role of foreign aid on savings and growth. South Asia has been the habitants of one fourth of the World population. The average annual growth rate per capita in the region in 2008 is 5.42 percent and it received $\$ 12.3$ billion net foreign aid in the same year which ranks third position in the World Bank regional Classification. ${ }^{2}$ The region has several things in common - historical tie, cultural affinity, relatively homogenous economic set up with GDP per capita ranging from \$524 in Nepal to \$2375 in Sri-Lanka in current US dollar in 2010. Many studies have investigated the effectiveness of foreign aid on growth for individual South Asian countries ${ }^{3}$ but very few studies have been done for all South Asian countries. Additionally, very few studies have tested the impact of foreign aid on both growth and saving simultaneously. The present study intents to fill this gap in the literature. Similarly, most of prior studies have used a linear regression with some control variables to analyze aid-growth relationship. A well accepted weakness of this technique is the failure to consider the likely simultaneity between growth and savings. We, therefore, develop a simultaneous equation system to fix the endogeneity problem.

The paper proceeds as follows: section II deals with the methodology used in the empirical analysis, in section III the empirical analysis is presented. In section IV, robustness check is conducted and finally, section V offers conclusions and policy implications.

\section{METHODOLOGY}

Estimation of growth and saving equations separately may suffer from simultaneous equations bias because some of explanatory variables may not be truly exogenous (Gupta and Islam, 1983). Therefore we estimate growth and saving equations simultaneously.

\footnotetext{
${ }^{1}$ SAARC stands for South Asian Association for Regional Cooperation and its member countries are: Bangladesh, Bhutan, India, Maldives, Nepal, Pakistan, and Sri-Lanka.

2 The world Bank's regional classification: East Asia and Pacific, Europe and Central Asia, Latin America and Caribbean, Middle East and North Africa, South Asia, Sub-Saharan Africa. The highest net aid recipient country is Sub-Saharan Africa followed by Middle East and North Africa. Source: WDI database.

${ }^{3}$ See, for example, Islam (1992), Bhattarai (2009).
} 
The simultaneous-equation model consists of a growth equation and a saving equation. The model is common in the literature (e.g. see Burke and Ahmadi-Esfahani, 2006).

$$
\begin{aligned}
& \operatorname{ggdp}_{i t}=\alpha_{i}+\beta_{1} \text { aid }_{i t}+\beta_{2} \text { saving }_{i t}+\beta_{3} \text { opennes }_{i t}+\beta_{4} \text { fiscDisc }_{i t}+u_{i t} \\
& \text { saving }_{i t}=c_{i}+\delta_{1} \text { aid }_{i t}+\delta_{2} \text { ggdp }_{i t}+\delta_{3} \text { openness }_{i t}+\delta_{4} \text { invest }_{i t}+v_{i t}
\end{aligned}
$$

where:

ggdp is the growth rate of real GDP at constant 2000 US dollar

aid defined as foreign aid (\% of GDP which includes both official development assistance (ODA) and official aid)

saving is the saving rate measured as a ratio of gross saving to GDP

openness is the trade openness measured by the sum of exports plus imports as a share of GDP

invest is the investment as a ratio of gross domestic investment to GDP, fiscal discipline

(fisDisc) is the government consumption expenditure (\% of GDP) as a proxy for fiscal discipline, and

$u_{i t}$ and $v_{i t}$ are error terms

The rationale behind controlling fiscal discipline in our model is that there has always been controversy over the appropriate use of aid. The government of recipient countries uses the aid fund in some other areas other than for the purpose it is given. The government consumption is a proxy for fiscal discipline which includes all government current expenditures for purchases of goods and services and most expenditures on national defense and security.

Trade openness (openness) is a policy variable that is measured by the sum of exports plus imports. Openness is considered to have great impact on growth through the exploitation of resources and economies of scale. One of our main concerns is whether foreign aid complements domestic savings in order to increase total investment in the economy. So our inclusion of domestic investment as an explanatory variable is relevant. Additionally, a country's growth positively depends on domestic investment.

The Equations (1) and (2) are exactly identified and are estimated by Two Stage Least Squares (TSLS) method for the five South Asian countries for the period 1960 to 2008 by pooling the annual time-series and crosssectional. The TSLS is employed to fix the simultaneous problem. This study differs from other studies at least in terms of time-series (longer period) and methodology. It covers the longest period possible. The data are obtained from the World Development Indicators.

\section{EMPIRICAL RESULTS}

The 2SLS estimates of Equations (1) and (2) are presented in Table 1. The results provide sufficient evidence to conclude that foreign aid has a positive impact on growth and negative impact on domestic savings. The impact of aid on growth is positive and statistically significant at the 1 percent level. The estimated results suggest that a $1 \%$ increase in foreign aid is estimated to increase growth by .76\% and reduce savings by .64\% for five South Asian countries over the period 1960 to 2008.

Table 1: 2SLS Estimation

\begin{tabular}{lccccccc}
\hline & con & aid & ggdp & saving & openness & fisdisc & invest \\
\hline \multirow{2}{*}{ ggdp } & -11.03 & $0.76^{* * *}$ & -- & $1.50^{* * *}$ & $-0.22^{* * *}$ & $0.32^{*}$ & -- \\
& $(2.83)$ & $(0.22)$ & -- & $(0.15)$ & $(0.02)$ & $(0.17)$ & \\
\multirow{4}{*}{ saving } & & & & & & & \\
& 4.49 & $-0.64^{* * *}$ & $0.34^{* * *}$ & -- & 0.05 & - & $0.35^{* *}$ \\
& $(1.21)$ & $(0.10)$ & $(0.10)$ & -- & $(0.30)$ & -- & $(0.16)$ \\
\hline
\end{tabular}

$\mathrm{R}^{2}: 0.38$ and 0.62 for equation (1) and (2) respectively. Figures in parentheses are standard error of the estimation, and ***, ***,* indicate significant at $1 \%, 5 \%$, and $10 \%$ levels respectively. 
The results from model 1 indicate that savings have a statistically significant impact on the growth rates of the five countries. One interesting point to note in growth regression is that saving affects growth rate more than proportionately that is a $1 \%$ increase in the domestic saving rate causes growth to increase by more than $1 \%$ on average i.e. $1.5 \%$. The growth rate of export and import, however, has a negative association with the rate of economic growth. One possible reason could be once a country liberalizes its trade policy import may outweigh export significantly thereby lowering growth. In our specification openness is defined by export plus import. As expected, government consumption expenditure which is a proxy for fiscal discipline contributes positively to economic growth. The impact of government expenditure is significant at the $10 \%$ level.

The results from model 2 suggest that aid adversely affects domestic saving in South Asian countries during the study period. This result is interesting at least for two reasons. First, most of the past studies (see, e.g., Dowling and Heimanz, 1983; Rana and Dowling, 1988; Burke and Ahmadi-Esfahani, 2006) on South Asian context have found that aid complements domestic savings. Our findings strongly stand against it. Foreign aid is crowding out domestic savings in the countries under consideration. Second, this result validates the idea that the governments of aid recipient country do not raise taxes but expand consumption from money coming from external sources which results in lower saving and thereby low growth. The effect on GDP growth and domestic investment is quite satisfactory. These variables are statistically significant at any conventional level. As opposed to the effect of openness on growth it has a positive association with the saving, though statistically not significant.

\section{ROBUSTNESS CHECK}

In the early 1990s most the SAARC countries implemented several reform programs that include liberalizing trade and economic policies. In this section we further examine whether the impact of foreign aid has been different during the post reform period. In doing so, we utilize the post reform period of 1990 to 2008.

Table 2: 2SLS Estimation for the Post Reform Period (1990-2008)

\begin{tabular}{|c|c|c|c|c|c|c|c|}
\hline & con & aid & $\operatorname{ggdp}$ & saving & openness & fisdisc & invest \\
\hline $\operatorname{ggdp}$ & $\begin{array}{c}-25.94 * * * \\
(2.76)\end{array}$ & $\begin{array}{c}1.26 * * * \\
(0.19)\end{array}$ & $\begin{array}{l}-- \\
--\end{array}$ & $\begin{array}{c}1.89 * * * \\
(0.12)\end{array}$ & $\begin{array}{c}-0.14 * * * \\
(0.02)\end{array}$ & $\begin{array}{c}0.53 * * * \\
(0.14)\end{array}$ & -- \\
\hline saving & $\begin{array}{c}7.33 * * * \\
(1.75)\end{array}$ & $\begin{array}{c}-0.78 * * * \\
(0.09)\end{array}$ & $\begin{array}{c}0.19 * * \\
(0.09)\end{array}$ & $\begin{array}{l}-- \\
--\end{array}$ & $\begin{array}{l}-0.01 \\
(0.02)\end{array}$ & $\begin{array}{l}-- \\
--\end{array}$ & $\begin{array}{c}0.48 * * * \\
(0.15)\end{array}$ \\
\hline
\end{tabular}

$\mathrm{R}^{2}: 0.84$ and 0.86 for equation (1) and (2) respectively. Figures in parentheses are standard error of the estimation, and $* * *, * * * *$ indicate significant at $1 \%, 5 \%$, and $10 \%$ levels respectively.

We report the results of the post reform period in Table 2. Clearly, the estimated results confirm our main findings that while foreign aid has a positive impact on growth, it has a crowding out effect on domestic saving in South Asia. Therefore, our results are robust.

\section{CONCLUSION}

This study examines the effectiveness of foreign aid on growth and domestic savings using a simultaneous equation system. The major finding of this paper is that foreign aid has a positive and significant impact on growth in five South Asian countries. Our results reveal a negative relationship between foreign aid and domestic savings and there is no ambiguity that foreign aid adversely affects domestic savings in South Asian Countries during the study period. The results are robust. Our results bring up a very important policy issue that is the positive effect of aid on growth might be offset by the negative effect on domestic saving. Hence, aid recipient countries should weigh the net effect.

\section{AUTHOR INFORMATION}

Hem C. Basnet, Ph.D., Assistant Professor, Department of Economics, Chadron State College, Chadron, NE 69337. Hem C. Basnet recieved his doctoral degree in Economics at Southern Illinois University and Dr. Basnet is an Assistant professor of Economics and Finance at Chadron state college, Nebraska, USA. E-mail: hbasnet@csc.edu 


\section{REFERENCES}

1. Asteriou, D. (2009). Foreign aid and economic growth: New evidence from a panel data approach for five south Asian countries. Journal of Policy Modeling, 31, 155-161.

2. Bhattarai, B. P. (2009). Foreign Aid and Growth in Nepal: An Empirical Analysis. The Journal of Developing Areas , 42(2), 283-302.

3. Boone, P. (1996). Politics and the Effectiveness of Foreign Aid. European Economic Review, 40, 289-329.

4. Burke, P. J. and Ahmadi-Esfahani, F. Z. (2006). Aid and Growth: A Study of South East Asia. Journal of Asian Economics, Vol. 17(2) p 350-362.

5. Burnside, C. and Dollar, D. (2000). Aid, Policies and Growth. American Economic Review, 90, 847-868.

6. Chenery, H.B., and Strout, A. M. (1966). Foreign Assistance and Economic Development. American Economic Review, 56, 679-733.

7. Dhakal, D., Upadhyaya, K. and Upadhyaya, M. (1996). Foreign Aid, Economic Growth and Causality. Rivista Internazionale di Scienze Economiche eCommerciali, 43, 597-606.

8. Dowling, J.M. and Heimenz, U. (1983). Aid, Savings, and Growth in the Asian region. Developing Economies, 21, 3-13.

9. Fayissa, B. and El-Kaissy, M.I. (1999). Foreign Aid and Economic Growth of Developing. Studies in Comparative Internatinal Development.

10. Griffin, K. B. (1970). Foreign Capital, Domestic Savings and Economic Development. Oxford Bulletin of Economics and Statistics, 32, 99-112.

11. Gupta, K. L. and Islam, M.A. (1983). Foreign capital, savings and growth: an international cross-section study, D. Reigel Publishing Co., Dordrecht.

12. Hatemi-J, A. and Manuchehr, I. (2005). Foreign aid and economic growth: new evidence from cointegration. Journal of Economic Development, 30(1), 71-80.

13. Islam, A. (1992). Foreign aid and Economic Growth: an Econometric Study of Bangladesh, Applied Economics, 24, 541-544.

14. Papanek, G. (1973). Aid, Foreign Private Investment, savings, and Growth in Less Developed Countries. Journal of Political Economy, 120-130.

15. Rajan, R. G. and Subramanian, A. (2008). Aid and Growth: what does the cross-country evidence really show?. The Review of Economics and Statistics, 90(4), 643-665.

16. Rana, P.B. and Dowling, J. (1988). The Impact of Foreign Capital on Growth. Evidence from Asian Developing Countries. Developing Economies, 26, 3-11. 
NOTES 